Published in final edited form as:

Anal Chem. 2016 February 16; 88(4): 2392-2398. doi:10.1021/acs.analchem.5b04409.

\title{
Absolute Quantitative MALDI Imaging Mass Spectrometry: A Case of Rifampicin in Liver Tissues
}

\author{
Chad W. Chumbley ${ }^{\dagger}$, Michelle L. Reyzer ${ }^{\ddagger}$, Jamie L. Allen ${ }^{\ddagger}$, Gwendolyn A. Marriner§, Laura

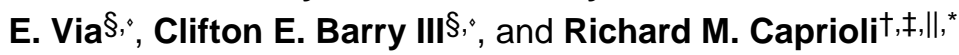 \\ †Department of Chemistry, Vanderbilt University, Nashville, Tennessee 37235, United States \\ ¥Mass Spectrometry Research Center, Vanderbilt University, Nashville, Tennessee 37240, United \\ States
}

§Tuberculosis Research Section, Laboratory of Clinical Infectious Diseases, National Institute of Allergy and Infectious Diseases, National Institutes of Health, Bethesda, Maryland 20892, United States

'Institute of Infectious Disease and Molecular Medicine, Department of Clinical Laboratory Sciences, University of Cape Town, Cape Town, South Africa

|Departments of Pharmacology, Biochemistry, and Medicine, Vanderbilt University, 46521 st Avenue South, Medical Research Building III, Nashville, Tennessee 37240, United States

\begin{abstract}
Matrix-assisted laser desorption/ionization (MALDI) imaging mass spectrometry (IMS) elucidates molecular distributions in thin tissue sections. Absolute pixel-to-pixel quantitation has remained a challenge, primarily lacking validation of the appropriate analytical methods. In the present work, isotopically labeled internal standards are applied to tissue sections to maximize quantitative reproducibility and yield accurate quantitative results. We have developed a tissue model for rifampicin (RIF), an antibiotic used to treat tuberculosis, and have tested different methods of applying an isotopically labeled internal standard for MALDI IMS analysis. The application of the standard and subsequently the matrix onto tissue sections resulted in quantitation that was not statistically significantly different from results obtained using HPLC-MS/MS of tissue extracts. Quantitative IMS experiments were performed on liver tissue from an animal dosed in vivo. Each microspot in the quantitative images measures the local concentration of RIF in the thin tissue section. Lower concentrations were detected from the blood vessels and around the portal tracts.
\end{abstract}

"Corresponding Author: Phone: 615-322-4336. r.caprioli@ vanderbilt.edu.

The authors declare no competing financial interest.

\section{ASSOCIATED CONTENT}

Supporting Information

The Supporting Information is available free of charge on the ACS Publications website at DOI: 10.1021/acs.anal-chem.5b04409. Synthesis of ${ }^{13} \mathrm{C},{ }^{2} \mathrm{H}-\mathrm{RIF}, \mathrm{MS} / \mathrm{MS}$ analysis of RIF and the internal standard showing the structure of the fragments with the analysis of the blank matrix, analysis of the droplet size volume from Portrait 630, a diagram of the microspots applied to tissue sections when testing the four different methods, graphs of the detected RIF and ${ }^{13} \mathrm{C},{ }^{2} \mathrm{H}-\mathrm{RIF}$ intensities from a single trial analyzing the different methods of standard application, the four quantitative MALDI MS/MS images of the tissue dosed in vivo, and the calibration curve data with RSDs for the four trials of quantitative MALDI IMS of the tissue dosed in vivo. (PDF) 
The quantitative values obtained from these measurements were comparable ( $>90 \%$ similarity) to HPLC-MS/MS results obtained from extracts of the same tissue.

\section{Graphical Abstract}

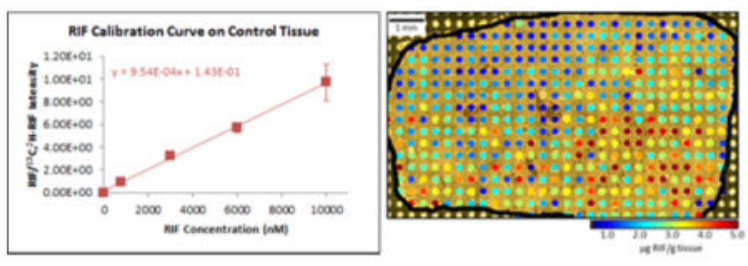

Since the detection of peptides, proteins, and pharmaceutical drugs directly from tissue sections using matrix-assisted laser desorption/ionization mass spectrometry (MALDI MS) was first demonstrated, ${ }^{1,2}$ MALDI imaging mass spectrometry (IMS) has become an increasingly effective tool used to measure the distribution of compounds within tissue sections. The technology finds a high level of utility in the pharmaceutical industry for the determination of the distributions of potential therapeutic agents and their metabolite(s). The quantitative capability of MALDI IMS from tissue sections has typically been reported through the correlation of the signal response to that from classical analytical techniques, including high-performance liquid chromatography-mass spectrometry (HPLC-MS), ${ }^{3-6}$ quantitative whole body autoradiography (QWBA) ${ }^{6}$ and gas chromatography with electron capture detection. ${ }^{7}$ Although HPLC-MS has been successful in achieving absolute quantitation, information on the localization of the drug within tissue substructures is lost during the tissue homogenization. While QWBA provides quantitative localization, it requires synthesis of a radioactive label and produces images of molecules containing the label that do not distinguish the drug from its metabolites.

MALDI IMS provides spatial and molecular specificity by directly detecting a unique $\mathrm{m} / Z$ for the compound of interest at specific coordinates in the tissue section. This technology also has the advantage of requiring small amounts of tissue ( $12 \mu \mathrm{m}$ section of $\sim 0.5 \mathrm{mg}$ vs $\sim 50 \mathrm{mg}$ for homogenization). Absolute quantitation by MALDI IMS has remained challenging because of matrix and tissue heterogeneity, inefficient analyte extraction, and ionization suppression effects. Furthermore, validating pixel-to-pixel quantitative MALDI IMS is difficult, because few other analytical technologies have the ability to quantitatively analyze pharmaceutical drugs in specific regions in an imaging experiment $(\sim 10-500 \mu \mathrm{m}$ diameter spot on a 3-20 $\mu \mathrm{m}$ thick tissue section).

One approach to quantitative IMS is the creation of surrogate tissue models in which a tissue homogenate dosed with varying concentrations of the analyte is prepared and then compared to an entire tissue section from a tissue dosed in vivo. ${ }^{8-10}$ This requires preparing a tissue homogenate spiked with different concentrations of the drug for each micro-environment in a tissue (e.g., medulla and cortex of the kidney or white and gray matter of the brain). Others have used a tissue extinction coefficient that must be evaluated for each analyte in every microenvironment of the tissue. ${ }^{11} \mathrm{~A}$ standard addition method in which calibration standards are applied to the dosed tissue section has also been utilized to determine the concentration 
of small molecules in tissue sections by MALDI IMS. ${ }^{12-14}$ Though data utilizing these published methods correspond well with HPLC-MS results, they remove the spatial advantage of IMS by reducing the analysis to a bulk quantitative measurement of the analyte within the entire tissue section, thereby largely ignoring the microenvironments within the tissue.

The utilization of an isotopically labeled internal standard has been reported in IMS experiments to correct for sample heterogeneity, extraction, and ionization suppression. ${ }^{15}$ However, the application and analysis of the internal and calibration standards have only been validated for the entire tissue section in bulk and not for the microenvironments within a tissue section. ${ }^{16-19}$ Current methods for internal standard application for IMS reported in the literature include: deposition directly onto the tissue followed sequentially by matrix application, ${ }^{12,20-23}$ deposition onto the target prior to tissue application, ${ }^{13,14,24-26}$ and deposition of the standards premixed with the matrix onto the tissue ${ }^{11,27-31}$ (see Figure 1). Using these methods, calibration standards are applied to an adjacent, nondosed tissue section. In order to provide accurate quantitation, the applied standard must mimic the interaction, ionization, and desorption of the analyte in tissues from dosed animals. The internal standard must also be homogeneous throughout the area analyzed. While these methods have demonstrated quantitative imaging capabilities, no validation of the quantitation on the microenvironments within the tissue section has been performed; therefore, they have provided limited spatial information.

We describe herein a multistep approach to systematically evaluate quantitative MALDI IMS on the scale of a single microspot using an isotopically labeled internal standard. First, a method to homogeneously dose tissues in vitro was developed to create standard tissues for the evaluation of the accuracy and precision of several different methods of microspotted standard application. The standard tissue minimizes questions surrounding the heterogeneity of drug distribution in tissues dosed in vivo on the size scale of the microspots. In addition, another method was evaluated where the standard is applied both before and after thawmounting the tissue section to the target (Figure 1). In these experiments, a robotic spotter was used to reproducibly and accurately deposit small volumes of solutions in discrete microspots across a surface. ${ }^{32}$ The solutions included the calibration standards applied to nondosed tissue sections and the internal standard for the analysis of dosed tissue sections. The microspots on the tissue sections had a diameter of $203.6 \pm 8.2 \mu \mathrm{m}$ and were used to define the pixels in the subsequent MALDI IMS experiment. Therefore, the extraction and analysis of the drug from the externally applied calibration standard solutions were as similar as possible to that of the drug in tissues dosed in vitro and in vivo. Since the calibration microspots and those on the dosed tissue were equal in size, microspots of a quality control solution were analyzed to ensure the accuracy and precision of the quantitative method for each experiment. This approach was used to apply an array of internal standard and matrix microspots onto a section of liver tissue from a dosed animal for quantitative MALDI IMS, demonstrating the localization of the antituberculosis drug rifampicin throughout the tissue section in the first quantitative images validated on the same size scale as the calibration curve. The average of the entire tissue section compared favorably to HPLC-MS/MS results from the bulk tissue homogenate, confirming the 
accuracy of this approach. This procedure allowed us to quantify the drug in the microenvironments within the tissue and measure local drug concentrations.

\section{EXPERIMENTAL SECTION}

\section{Materials}

Standard rifampicin (RIF) and 2,4,6-trihydrox-yacetophenone (THAP) were obtained from Sigma-Aldrich (St. Louis, MO). The internal standard $\left({ }^{13} \mathrm{C},{ }^{2} \mathrm{H}-\mathrm{RIF}\right)$ was synthesized (Supporting Information) by adapting previously published methods. ${ }^{33-36}$ Ethanol (200 proof) was acquired from Pharco-AAPER (Brookfield, CT), and $18 \mathrm{M} \Omega$ water was obtained from a Milli-Q water purification system (Millipore, Billerica, MA). Rat liver tissues were purchased from Pel-Freez Biologicals (Rogers, AR).

\section{Sample Preparation and Analysis of Homogeneity in the Tissues Dosed in vitro}

Tissues dosed in vitro were prepared by immersing two rat liver pieces in a RIF solution (50 $\mu \mathrm{M}$ in water). Liver tissue was chosen because of its mostly homogeneous environment. After $24 \mathrm{~h}$ of immersion with agitation, the liver pieces were removed from the solution, rinsed with distilled water, flash-frozen, and stored at $-80^{\circ} \mathrm{C}$ until further analysis.

One liver dosed in vitro was cryosectioned (12 $\mu \mathrm{m}$ thick) and thaw-mounted onto a goldcoated stainless steel target. Two different $12 \mu \mathrm{m}$ thick sections with five $100 \mu \mathrm{m}$ thick sections discarded in between them were thaw-mounted onto the target. Matrix $(20 \mathrm{mg} / \mathrm{mL}$ THAP in 50\% ethanol/water) was manually applied using a thin-layer chromatography reagent sprayer (Kontes Glass Company, Vinland, NJ).

The sections were then analyzed at a spatial resolution of $200 \mu \mathrm{m}$ using a linear ion trap mass spectrometer equipped with a MALDI source (LTQ XL, Thermo Scientific, Waltham, MA). The precursor ion for $\operatorname{RIF~}(\mathrm{m} / z 821.4 \pm 0.5)$ was selected in negative ion mode and fragmented using a normalized collision energy of $45 \%$. The primary transition for RIF was $\mathrm{m} / z 821$ to 397. Images of the fragment ion $\mathrm{m} / z 397$ were generated (ImageQuest, Thermo Scientific) and compared for homogeneity.

\section{Methods of Internal Standard Application}

The internal standard $\left(10 \mu \mathrm{M}{ }^{13} \mathrm{C},{ }^{2} \mathrm{H}-\mathrm{RIF}\right.$ in $50 \%$ ethanol/water) was deposited using an acoustic robotic spotter (Portrait 630, Labcyte, Sunnyvale, CA) onto $12 \mu \mathrm{m}$ thick sections of two different tissues dosed in vitro. A total of 24 microspots were applied to the liver sections using each method shown in Figure 1. The calibration standards (1.0-10 $\mu \mathrm{M}$ RIF with $10 \mu \mathrm{M}{ }^{13} \mathrm{C},{ }^{2} \mathrm{H}$-RIF in 50\% ethanol/water) were deposited using each method onto 12 $\mu \mathrm{m}$ thick sections of a nondosed liver tissue. A quality control concentration (5.0 $\mu \mathrm{M}$ RIF with $10 \mu \mathrm{M}{ }^{13} \mathrm{C},{ }^{2} \mathrm{H}-\mathrm{RIF}$ ) was also deposited using each method to ensure accuracy in the application of the standards. Eight different microspots were averaged for each concentration to construct the calibration curve for each method (a diagram of all microspots is in Supporting Information Figure 2). Matrix ( $20 \mathrm{mg} / \mathrm{mL}$ THAP in $50 \%$ ethanol/water) was applied after the internal and calibration standards for all methods except for premixing. When premixing the standards with the matrix, $20 \mathrm{mg} / \mathrm{mL}$ THAP was included in each 
solution. For the standards and matrix applications, 20 passes of 2 droplets $(171.3 \pm 10.1 \mathrm{pL} /$ droplet; measurements described in Supporting Information) were deposited using the Portrait 630 with $60 \mathrm{~s}$ between each pass to allow for drying.

A total of 13 analytical scans with 6 microscans of 5 laser shots each was collected using the LTQ XL MS for each spot to average the signal throughout the entire area (200 $\mu \mathrm{m}$ diameter circle). The precursor ions for RIF and ${ }^{13} \mathrm{C},{ }^{2} \mathrm{H}-\mathrm{RIF}$ were selected in a large isolation window $(\mathrm{m} / z 822.4 \pm 1.5)$ and fragmented using a normalized collision energy of $45 \%$. Spectra for RIF and ${ }^{13} \mathrm{C},{ }^{2} \mathrm{H}$-RIF with THAP as a matrix and for THAP alone spotted onto a control tissue section are shown in Supporting Information Figure 1 demonstrating no biological or matrix interferences in the analysis. Calibration curves were generated by plotting the average intensity area ratio of the major fragment ion of RIF to the manually corrected (for the isotopic contribution from unlabeled RIF) intensity area of the major fragment ion of ${ }^{13} \mathrm{C},{ }^{2} \mathrm{H}-\mathrm{RIF}[\mathrm{m} / \mathrm{z} 397 / \mathrm{m} / \mathrm{z}$ 399] versus the concentration of RIF applied to the tissue section ( 8 microspots for each concentration). The intensity area ratios were generated using MALDIQuan software (Thermo Scientific). The correction for the internal standard intensity is required to account for the contribution of unlabeled RIF $(4.16 \%)$ to the $[\mathrm{M}-\mathrm{H}+2]^{-}$ion from the naturally occurring isotopes of the atoms in the molecule $\left({ }^{13} \mathrm{C},{ }^{2} \mathrm{H},{ }^{17} \mathrm{O},{ }^{18} \mathrm{O}\right.$, and $\left.{ }^{15} \mathrm{~N}\right)$.

The total amount of RIF deposited is known, since the Portrait 630 delivers $171.3 \pm 10.1 \mathrm{pL} /$ droplet. The density of liver tissue is assumed to be equal to that of water $(1.05 \mathrm{~g} / \mathrm{mL}),{ }^{13,15}$ and the diameter of the microspots was measured to be $203.6 \pm 8.2 \mu \mathrm{m}(\mathrm{n}=8)$. A cylinder of tissue (12 $\mu \mathrm{m}$ tall with a diameter of $200 \mu \mathrm{m})$ was used to calculate the tissue's mass for each spot to compare to HPLC-MS/MS.

\section{Sample Preparation and Analysis of Tissues Dosed in vivo using Quantitative MALDI IMS}

The optimal method for applying the internal standard and calibration standards was determined to be the deposition of the standard and the matrix sequentially onto the tissue sections (discussed later and in Figure 3). All in vivo animal studies were conducted at the NIH laboratories under guidelines of the institutional animal care and use committee of the NIAID (PHS Assurance \#A4149-01). A New Zealand white rabbit infected with Mycobacterium tuberculosis was orally administered a cocktail of rifampicin, isoniazid, pyrazinamide, and moxifloxacin (30/50/125/25 mg/kg) once daily for 1 week and was sacrificed $4 \mathrm{~h}$ and $21 \mathrm{~min}$ after the final dose according to previously published methods. ${ }^{37}$ The liver tissue was flash-frozen, gamma-irradiated to sterilize the infection, and stored at $-80{ }^{\circ} \mathrm{C}$ until analysis. The internal standard $\left(10 \mu \mathrm{M}{ }^{13} \mathrm{C},{ }^{2} \mathrm{H}\right.$-RIF in $50 \%$ ethanol/water $)$ was deposited onto a $12 \mu \mathrm{m}$ section of the dosed tissue in a $350 \times 350 \mu \mathrm{m}$ microspotted array using the Portrait 630. Calibration standards (1.0-10 $\mu \mathrm{M}$ RIF with $10 \mu \mathrm{M}{ }^{13} \mathrm{C},{ }^{2} \mathrm{H}-\mathrm{RIF}$ in $50 \%$ ethanol/water including a quality control solution of $5.0 \mu \mathrm{M}$ RIF) were deposited onto a nondosed tissue section followed by matrix $(20 \mathrm{mg} / \mathrm{mL}$ THAP in $50 \%$ ethanol/water) deposition. This allows for the calibration microspots (including the quality control) and the analyzed microspots on the dosed tissue section to be equal in size. The quality control solution was used to determine the accuracy and precision of the method. A total of eight microspots were deposited for each concentration on the calibration curve. Each individual 
microspot was analyzed on the LTQ as previously described, and the quantitative image was generated with in-house software developed using MATLAB.

\section{Homogenization and Analysis by HPLC-MS/MS}

The dosed liver tissues and a control liver tissue were cut ( $\sim 80 \mathrm{mg}$ ), homogenized in $10 \%$ methanol/water $(\sim 30 \mathrm{mg} / \mathrm{mL})$, and analyzed similar to a previously published method. ${ }^{38}$ Stock solutions of RIF $(0.466 \mathrm{mg} / \mathrm{mL})$ and ${ }^{13} \mathrm{C},{ }^{2} \mathrm{H}-\mathrm{RIF}(0.376 \mathrm{mg} / \mathrm{mL})$ were used to spike calibration standards $\left(2.58 \times 10^{-3}\right.$ to $5.16 \times 10^{-1} \mu \mathrm{g}$ RIF with $\left.1.88 \times 10^{-1} \mu \mathrm{g}{ }^{13} \mathrm{C},{ }^{2} \mathrm{H}-\mathrm{RIF}\right)$ into $150 \mu \mathrm{L}$ of the control liver homogenate. Only the internal standard was spiked into 150 $\mu \mathrm{L}$ of the dosed tissue homogenates. All samples were diluted with methanol to a final volume of $800 \mu \mathrm{L}$ and were centrifuged at 10,000 rpm for $10 \mathrm{~min}$. The supernatants of the tissue homogenates were separated by reversed phase liquid chromatography using a C18 column $(30 \times 2 \mathrm{~mm}$, Luna $3 \mu \mathrm{m}, 100 \AA \AA$ A Phenomenex, Torrance, CA) and analyzed on a triple quadrupole MS/MS instrument (Thermo TSQ Quantum or Agilent 6430). The solvents used for the HPLC separation were $0.1 \%$ formic acid in water (A) and methanol (B). The gradient was as follows: linearly decrease from $90 \%$ to $10 \%$ solvent A over 5 min, hold for 1 min, linearly increase to $90 \%$ solvent A in $1 \mathrm{~min}$, and hold for three more minutes. The transitions of $\mathrm{m} / z 821$ to 397 (RIF) and $\mathrm{m} / z 823$ to $399\left({ }^{13} \mathrm{C},{ }^{2} \mathrm{H}\right.$-RIF) were monitored and the retention times were approximately $5.1 \mathrm{~min}$. The dosed tissue homogenates were compared to the spiked calibration standards to determine the amount of RIF present in the dosed tissues.

\section{RESULTS AND DISCUSSION}

\section{Homogeneity of Tissues Dosed in vitro}

Imaging experiments with tissues dosed in vitro, collected at a lateral resolution of $200 \mu \mathrm{m}$, reveal the homogeneity of the dosing. The ion intensity image of the two $12 \mu \mathrm{m}$ thick tissue sections with $500 \mu \mathrm{m}$ of tissue discarded between them is shown in Figure 2A, with the hematoxylin and eosin H\&E stained serial sections in Figure 2B. An average MS/MS spectrum from the tissue is shown in Figure 2C, displaying the precursor ion at $m / z 821$ and the primary fragment ion of RIF at $\mathrm{m} / z$ 397. The ion intensity images of $m / z 397$ are scaled equivalently with a maximum intensity of $2.00 \mathrm{E} 3$ counts. The ion intensity localization is consistent between both sections indicating the tissue was homogeneously dosed. Furthermore, the intensities from $1 \mathrm{~mm} \times 1 \mathrm{~mm}$ regions throughout each tissue section covering the entire area were averaged together and were similar. The overall average intensities of these regions for the two sections were 1.25E $(n=38)$ and 1.21E3 $(n=32)$ counts, respectively. The relative standard deviations of the measurements from each tissue section were $14.9 \%$ and $13.9 \%$, respectively. These data indicate there was not a statistically significant difference between the intensities detected from the two sections of the same liver tissue. Thus, the liver tissues dosed in vitro were utilized to test the different methods of calibration and internal standard application for MALDI IMS experiments.

\section{Methods of Internal Standard Application}

Variations in analyte sensitivity caused by the method of internal standard application are expected due to the differential extraction of RIF from the tissue section. The addition of an 
internal standard should compensate for this effect and produce similar calibration curves. The calibration curves for each method of applying the standards generated by plotting the average intensity area ratio of RIF to the corrected ${ }^{13} \mathrm{C},{ }^{2} \mathrm{H}$-RIF intensity area $[\mathrm{m} / \mathrm{z} 397 / \mathrm{m} / z$ 399 (MALDIQuan Software, Thermo Scientific)] versus the concentration of RIF applied to the tissue section are shown in Figure 3A. The error bars in the graph represent the standard deviation of eight microspots for each of the calibration solutions. These similar calibration curves indicate the internal standard accounts for any extraction differences caused by the method of application. The errors in the quality control microspots also averaged less than $15 \%$ for each of the four methods of application. The average concentrations detected using each method for both tissues dosed in vitro are shown graphically in Figure 3B. The RIF concentrations represent the average of at least three MALDI MS/MS trials and at least five trials for HPLC-MS/MS using the same tissue homogenates with the error bars showing the standard deviations. Premixing the internal standard with the matrix yielded measured concentrations lower than those from HPLC-MS/MS, while depositing the standard prior to thaw-mounting the tissue provided measured concentrations higher than those from HPLCMS/MS. Comparisons to the HPLC-MS/MS data indicated depositing the standards on the tissue followed by the matrix was the most accurate.

An analysis of variance (ANOVA) was performed on the data from both tissues dosed in vitro to determine if there were statistical differences among the various methods of MALDI MS/MS quantitation and HPLC-MS/MS quantitation. The computed F statistic was 107 (pvalue $\left.=1.20 \times 10^{-58}\right)$ and $94.3\left(\mathrm{p}\right.$-value $\left.=9.81 \times 10^{-54}\right)$ for tissues 1 and 2 , respectively, indicating there was a statistical difference among the methods of standard application. A posthoc Tukey's test for differences was performed (Table in Figure 3C) to determine which methods were different from each other. When the test was performed on the data for tissue 1 , there were statistically significant differences from HPLC-MS/MS when the standards were deposited as a sandwich $(\mathrm{p}$-value $=0.033)$ and under the tissue $\left(\mathrm{p}\right.$-value $\left.=1.16 \times 10^{-9}\right)$. When the posthoc analysis was performed for tissue 2, there were statistically significant differences from HPLC-MS/MS when the standards were premixed with the matrix (p-value $\left.=3.11 \times 10^{-4}\right)$ and deposited under the tissue $\left(\mathrm{p}\right.$-value $\left.=1.28 \times 10^{-8}\right)$. Since depositing the standards onto the tissue section followed by matrix application was not statistically different from HPLC-MS/MS for either tissue, this method was determined to be the best for quantitative MALDI IMS of tissues dosed in vivo.

The optimal method of applying standards should mimic the response of the analyte from tissues dosed in vivo. Each method yielded similar intensities for the detection of RIF from the dosed tissues (Supporting Information Figure 3). Premixing the internal standard with the matrix allows them to cocrystallize with one another prior to reaching the tissue leading to a larger detected intensity for ${ }^{13} \mathrm{C},{ }^{2} \mathrm{H}$-RIF. A previous study also concluded premixing the standards with the matrix did not suffice as an internal standard for quantitative measurements of analytes in tissue sections. ${ }^{25}$ Depositing the standards under the tissue provided the highest amount of variability in the concentrations measured from the dosed tissues. Additionally, the internal standard response was the lowest for depositing it before tissue application and for depositing it as a sandwich when compared to the other methods. This is likely caused by the incomplete penetration of the internal standard through the tissue section when it is thaw-mounted yielding less extraction into the matrix for analysis. 
Because the robotic spotter deposits multiple droplets onto the tissue section, this provides better penetration and mixing of the internal standard into the thin tissue section as if it were dosed in vivo. Therefore, depositing standards on the section followed by the matrix using the robotic spotter mimics the analyte dosed in vivo and yields the most accurate concentrations for quantitative MALDI IMS.

\section{Quantitative IMS of Liver Tissue Dosed in vivo}

The metabolic mechanism for rifampicin in rabbit liver is not fully understood. The primary metabolic pathway is the deacetylation of the acetate at the $\mathrm{C}-25$ position, but the esterase enzyme responsible for this action in vivo remains unknown. ${ }^{39}$ The microspotted quantitative MALDI MS/MS image of RIF in the liver section (Figure 4A) shows a gradient of RIF concentration from the middle of the tissue section toward the bottom right. The concentration of the drug around the portal tracts is lower, which is consistent with the metabolic heterogeneity of hepatocytes throughout a liver tissue and is indicative of the microphysiology and zonation of the cytochrome P450 enzymes. ${ }^{40-43}$ Furthermore, less RIF was detected in the blood vessels (outlined in a black dotted line of Figure 4), likely because the drug is bound to a blood protein such as albumin or $a$-1-acid glycoprotein as demonstrated previously where $70-80 \%$ of RIF was bound to each of these individually in vitro. $^{44}$

Each microspot in the quantitative image represents the amount of RIF in $\mu \mathrm{g} / \mathrm{g}$ tissue detected from the tissue section. No RIF was detected in the microspots surrounding the tissue section, and these were not included in the average concentration for MALDI IMS.

Each microspot of the quality control solution deposited onto the nondosed tissue section for each trial was greater than $90 \%$ accurate with most greater than $95 \%$. The relative standard deviations for the eight microspots of quality control were less than $10 \%$ for each of the four trials as well (Table in Supporting Information Figure 5). Additionally, an experiment analyzing eight replicates of calibration standards (50-100,000 nM RIF with 10,000 $\mathrm{nM}^{2} \mathrm{H},{ }^{13} \mathrm{C}$-RIF) was performed to determine the lower and upper limits of quantitation for these measurements. These limits are defined by the United States Food and Drug Administration as the lowest and highest concentrations with less than $20 \%$ precision around the mean. ${ }^{45}$ The lowest and highest concentrations of RIF with relative standard deviations less than $20 \%$ were $200 \mathrm{nM}$ RIF (11.9\%) and 20,000 nM RIF (9.83\%), respectively. Therefore, the quantitation range for these measurements spanned 2 orders of magnitude.

When the amounts of RIF detected from each of the microspots in the image shown in Figure 4A were averaged together and compared to results from a piece of the same liver analyzed by HPLC-MS/MS, the results were $90.4 \%$ similar (four trials for each analytical technology). All quantitative images for this tissue are shown in Supporting Information Figure 4. The amount detected by quantitative MALDI IMS was $2.29 \pm 0.26 \mu \mathrm{g}$ RIF/g tissue, and the amount detected by HPLC-MS/MS was $2.54 \pm 0.49 \mu \mathrm{g} \mathrm{RIF/g} \mathrm{tissue} \mathrm{(Table} \mathrm{in}$ Figure 4C). No statistically significant difference was found between these two sets of data. Though the overall localization of the drug differed among four different tissue sections (Supporting Information Figure 4), the localization within the microenvironments of each section remained the same, and the total RIF concentration measured from each section was 
consistent with a relative standard deviation of $11.4 \%$. These data support previous observations of a three-dimensional liver acinus in which drug concentrations vary as well as observations of the overall homogeneity of drug concentrations within livers. ${ }^{41}$ All of the tissue microenvironments contribute to this average from HPLC-MS/MS, but the quantitative MALDI IMS data elucidates the localization of RIF within the microenvironments.

\section{CONCLUSIONS}

Utilizing a tissue dosed in vitro, different methods of depositing internal and calibration standards to tissue sections for quantitative IMS using an acoustic robotic spotter were examined, and depositing the standards onto the section followed by the matrix was optimal and produced no statistically significant difference from HPLC-MS/MS results.

Once the method of standard application was validated, a quantitative image was generated, with each microspot representing a measured concentration of RIF from a $12 \mu \mathrm{m}$ thick section of a tissue dosed in vivo. The microspots in the image were equal in size to those reproducibly analyzed for the calibration curve (relative standard deviations less than 10\%) and for the quality control solution, allowing the method to be assessed on the scale of a single microspot. When the average concentration from quantitative MALDI IMS was compared to the concentration from HPLC-MS/MS data, the data were $90.4 \%$ similar. Quantitative MALDI IMS, however, provided additional information about the absolute concentration detected from the microenvironments within the tissue. Less RIF was detected from the blood vessels, and a gradient of RIF was also detected radiating from the portal tracts, indicating the microphysiology of metabolism within the liver.

Microspotted pixel-to-pixel quantitative MALDI IMS provides an absolute amount of an analyte present in a thin tissue section while preserving the spatial distribution. Utilizing calibration microspots equivalent in size to the microspots on the dosed tissue section allows for a quality control validation of the method. Currently, this method is limited by the spot size of the robotic spotter to a spatial resolution of approximately $250 \mu \mathrm{m}$. Robotic spotters having reduced droplet sizes and improved deposition accuracies will provide better resolution for future imaging experiments. Different tissues must also be explored in which there are multiple microenvironments (kidneys, brains, etc.) within a single tissue that may cause differential extraction and/or ionization of the analytes of interest. Though this method of quantitative MALDI IMS is expected to have quantitative functionality across all drug classes, other compounds with different chemical properties (hydrophobicity, molecular weight, etc.) would need to be evaluated.

\section{Supplementary Material}

Refer to Web version on PubMed Central for supplementary material.

\section{Acknowledgments}

The authors would like to thank Tina Tsui for development of the quantitative imaging software in MATLAB, Dr. Mary Kay Washington for assisting with the H\&E stains, Brian C. Hachey and Philip J. Kingsley for their assistance with the HPLC-MS/MS experiments, and Danielle Weiner and Dan Schimel of NIAID, NIH, for 
assistance with the rabbit experiments. This work was supported in part by NIH/NIGMS grants R01-GM058008 and P41-GM103391 to RMC, by the Intramural Research Program of NIAID, NIH (CEB), and the Bill and Melinda Gates Foundation Accelerator Program (\#705309 to J. Flynn, University of Pittsburgh). CWC would also like to acknowledge a fellowship from Aegis Sciences Corporation.

\section{References}

1. Caprioli RM, Farmer TB, Gile J. Anal Chem. 1997; 69:4751-4760. [PubMed: 9406525]

2. Troendle FJ, Reddick CD, Yost RA. J Am Soc Mass Spectrom. 1999; 10:1315-1321.

3. Reyzer ML, Hsieh YS, Ng K, Korfmacher WA, Caprioli RM. J Mass Spectrom. 2003; 38:10811092. [PubMed: 14595858]

4. Hankin JA, Murphy RC. Anal Chem. 2010; 82:8476-8484. [PubMed: 20853893]

5. Koeniger SL, Talaty N, Luo YP, Ready D, Voorbach M, Seifert T, Cepa S, Fagerland JA, Bouska J, Buck W, Johnson RW, Spanton S. Rapid Commun Mass Spectrom. 2011; 25:503-510. [PubMed: 21259359]

6. Takai N, Tanaka Y, Inazawa K, Saji H. Rapid Commun Mass Spectrom. 2012; 26:1549-1556. [PubMed: 22638972]

7. Lagarrigue M, Lavigne R, Tabet E, Genet V, Thome JP, Rondel K, Guevel B, Multigner L, Samson M, Pineau C. Anal Chem. 2014; 86:5775-5783. [PubMed: 24837422]

8. Groseclose MR, Castellino S. Anal Chem. 2013; 85:10099-10106. [PubMed: 24024735]

9. Takai N, Tanaka Y, Saji H. Mass Spectrom. 2014; 3:A0025.

10. Jadoul L, Longuespee R, Noel A, De Pauw E. Anal Bioanal Chem. 2015; 407:2095. [PubMed: 25326885]

11. Hamm G, Bonnel D, Legouffe R, Pamelard F, Delbos JM, Bouzom F, Stauber J. J Proteomics. 2012; 75:4952-4961. [PubMed: 22842155]

12. Goodwin RJA, Mackay CL, Nilsson A, Harrison DJ, Farde L, Andren PE, Iverson SL. Anal Chem. 2011; 83:9694-9701. [PubMed: 22077717]

13. Pirman DA, Yost RA. Anal Chem. 2011; 83:8575-8581. [PubMed: 21942933]

14. Pirman DA, Reich RF, Kiss A, Heeren RMA, Yost RA. Anal Chem. 2013; 85:1081-1089. [PubMed: 23214490]

15. Reich RF, Cudzilo K, Levisky JA, Yost RA. J Am Soc Mass Spectrom. 2010; 21:564-571. [PubMed: 20097576]

16. Stauber J. Bioanalysis. 2012; 4:2095-2098. [PubMed: 23013389]

17. Prideaux B, Stoeckli M. J Proteomics. 2012; 75:4999-5013. [PubMed: 22842290]

18. Kubo A, Kajimura M, Suematsu M. Mass Spectrom. 2012; 1:A0004.

19. Porta T, Lesur A, Varesio E, Hopfgartner G. Anal Bioanal Chem. 2015; 407:2177-2187. [PubMed: 25486918]

20. Hsieh Y, Casale R, Fukuda E, Chen JW, Knemeyer I, Wingate J, Morrison R, Korfmacher W. Rapid Commun Mass Spectrom. 2006; 20:965-972. [PubMed: 16470674]

21. Nilsson A, Fehniger TE, Gustavsson L, Andersson M, Kenne K, Marko-Varga G, Andren PE. PLoS One. 2010; 5:e11411. [PubMed: 20644728]

22. Fehniger TE, Vegvari A, Rezeli M, Prikk K, Ross P, Dahlback M, Edula G, Sepper R, Marko-Varga G. Anal Chem. 2011; 83:8329-8336. [PubMed: 21942412]

23. Clemis EJ, Smith DS, Camenzind AG, Danell RM, Parker CE, Borchers CH. Anal Chem. 2012; 84:3514-3522. [PubMed: 22356211]

24. Landgraf RR, Garrett TJ, Conaway MCP, Calcutt NA, Stacpoole PW, Yost RA. Rapid Commun Mass Spectrom. 2011; 25:3178-3184. [PubMed: 21953974]

25. Pirman DA, Kiss A, Heeren RMA, Yost RA. Anal Chem. 2013; 85:1090-1096. [PubMed: 23214468]

26. Buck A, Halbritter S, Spath C, Feuchtinger A, Aichler M, Zitzelsberger H, Janssen KP, Walch A. Anal Bioanal Chem. 2015; 407:2107. [PubMed: 25311193]

27. Bunch J, Clench MR, Richards DS. Rapid Commun Mass Spectrom. 2004; 18:3051-3060. [PubMed: 15543527] 
28. Prideaux B, Dartois V, Staab D, Weiner DM, Goh A, Via LE, Barry CE, Stoeckli M. Anal Chem. 2011; 83:2112-2118. [PubMed: 21332183]

29. Kallback P, Shariatgorji M, Nilsson A, Andren PE. J Proteomics. 2012; 75:4941-4951. [PubMed: 22841942]

30. Nakanishi T, Takai S, Jin D, Takubo T. Mass Spectrom. 2013; 2:A0021.

31. Schulz S, Gerhardt D, Meyer B, Seegel M, Schubach B, Hopf C, Matheis K. Anal Bioanal Chem. 2013; 405:9467-9476. [PubMed: 24121470]

32. Aerni HR, Cornett DS, Caprioli RM. Anal Chem. 2006; 78:827-834. [PubMed: 16448057]

33. Vijn RJ, Arts HJ, Green R, Castelijns AM. Synthesis. 1994; 1994:573-578.

34. Bartolucci C, Cellai L, Difilippo P, Segre A, Brufani M, Filocamo L, Bianco AD, Guiso M, Brizzi V, Benedetto A, Dicaro A, Elia G. Farmaco. 1992; 47:1367-1383. [PubMed: 1283514]

35. Brufani, M.; Cellai, L.; Bartolini, B.; Medici, I.; Lagrasta, BM. Patent WO. 200901055 A1. 2009.

36. Taguchi M, Yamane Y, Aikawa N, Tsukamoto G. Chem Pharm Bull. 1988; 36:4157-4161. [PubMed: 3245989]

37. Kjellsson MC, Via LE, Goh A, Weiner D, Low KM, Kern S, Pillai G, Barry CE III, Dartois V. Antimicrob Agents Chemother. 2012; 56:446-457. [PubMed: 21986820]

38. Fang PF, Cai HL, Li HD, Zhu RH, Tan QY, Gao W, Xu P, Liu YP, Zhang WY, Chen YC, Zhang F. J Chromatogr B: Anal Technol Biomed Life Sci. 2010; 878:2286-2291.

39. Nakajima A, Fukami T, Kobayashi Y, Watanabe A, Nakajima M, Yokoi T. Biochem Pharmacol. 2011; 82:1747-1756. [PubMed: 21856291]

40. Jungermann K, Katz N. Physiol Rev. 1989; 69:708-764. [PubMed: 2664826]

41. Katz NR. J Nutr. 1992; 122:843-849. [PubMed: 1542056]

42. Lindros KO. Gen Pharmacol. 1997; 28:191-196. [PubMed: 9013193]

43. Oinonen T, Lindros KO. Biochem J. 1998; 329:17-35. [PubMed: 9405271]

44. Woo J, Cheung W, Chan R, Chan HS, Cheng A, Chan K. Clin Biochem. 1996; 29:175-177. [PubMed: 8601328]

45. United States Food and Drug Administration. Guidance for Industry: Bioanalytical Validation. 2001. 


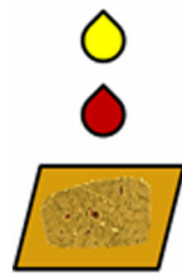

Standard

On Tissue

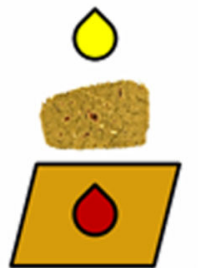

Standard Under Tissue

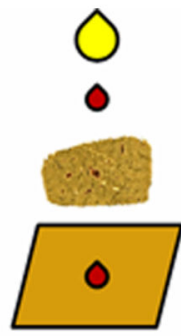

Standard

Sandwich

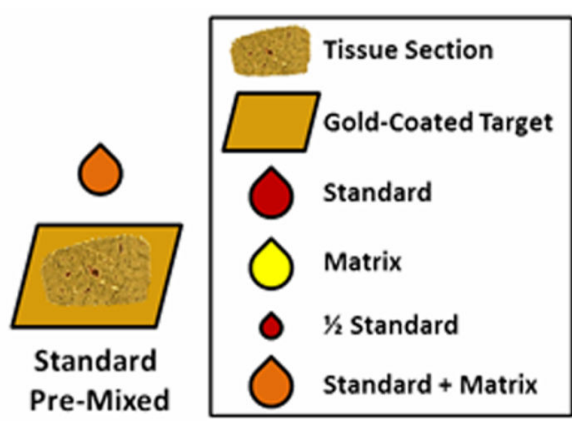

Figure 1.

Illustration of the four methods of applying standards for IMS. Depositing the standards on the tissue section requires thaw-mounting the section followed by application of the standards and matrix. Deposition under the tissue section requires spotting the standards first, thaw-mounting the section on top of them, and then applying matrix. A sandwich method combines depositing the standards under and on the tissue section followed by matrix. Premixing the standard involves thaw-mounting the tissue section followed by depositing the standards and the matrix in a single solution. 
A)

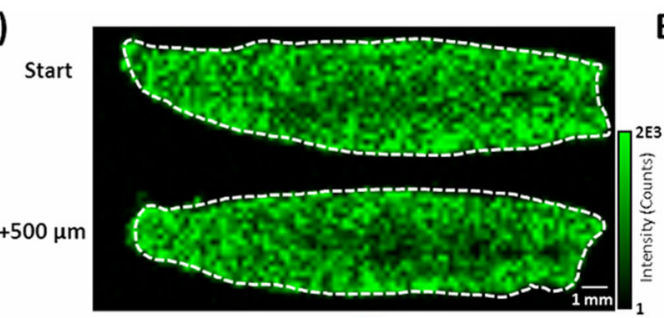

C)

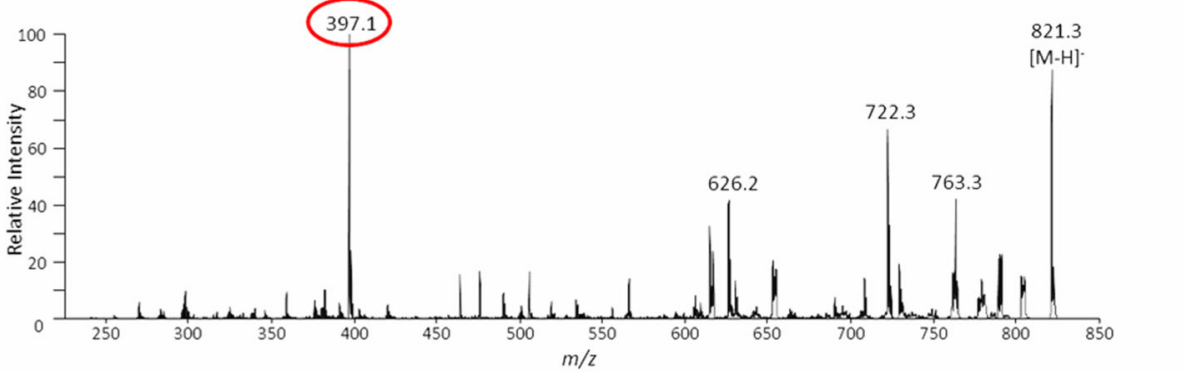

Figure 2.

(A) Mass spectrometry image analyzed at a spatial resolution of $200 \mu \mathrm{m}$ of the primary RIF fragment at $\mathrm{m} / z 397$ and (B) $\mathrm{H} \& \mathrm{E}$ serial section stains of two $12 \mu \mathrm{m}$ thick sections with 500 $\mu \mathrm{m}$ of the tissue discarded between them of a liver dosed in vitro with RIF. The image of the RIF fragment depicts the homogeneity of the dosing. (C) Average MS/MS spectrum from the dosed tissues with the primary fragment ion $\mathrm{m} / z 397$ circled in red. 

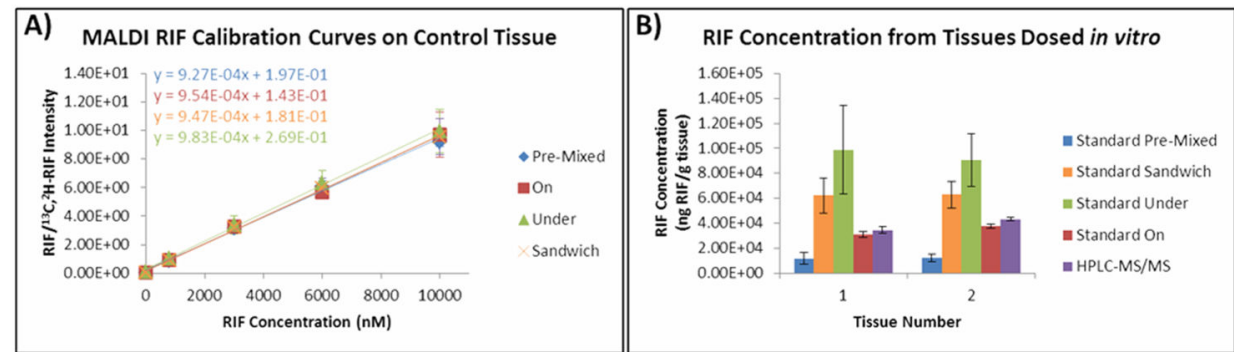

\begin{tabular}{|c|c|c|c|c|c|c|c|c|c|c|c|}
\hline \multicolumn{12}{|c|}{ Tukey's Test for Differences in Quantitation Methods } \\
\hline & & \multicolumn{5}{|c|}{ Tissue 1} & \multicolumn{5}{|c|}{ Tissue 2} \\
\hline \multirow[b]{2}{*}{ (I) Group } & \multirow[b]{2}{*}{ (J) Group } & \multirow[b]{2}{*}{ Mean Diff.(1-J) } & \multirow[b]{2}{*}{ Standard Error } & \multirow[b]{2}{*}{$p$-value } & \multicolumn{2}{|c|}{$95 \% \mathrm{Cl}$} & \multirow[b]{2}{*}{ Mean Diff. (I-J) } & \multirow[b]{2}{*}{ Standard Error } & \multirow[b]{2}{*}{$p$-value } & \multicolumn{2}{|c|}{$95 \% \mathrm{Cl}$} \\
\hline & & & & & Lower & Upper & & & & Lower & Upper \\
\hline \multirow{4}{*}{ HPLC } & Pre-Mixed & $2.28 \mathrm{E}+04$ & $9.53 \mathrm{E}+03$ & 0.120 & $-3.33 E+03$ & $4.89 \mathrm{E}+04$ & $3.12 \mathrm{E}+04$ & $7.41 \mathrm{E}+03$ & $3.11 \mathrm{E}-04^{*}$ & $1.09 \mathrm{E}+04$ & $5.16 E+04$ \\
\hline & On & $3.57 E+03$ & $9.70 E+03$ & 0.996 & $-2.30 E+04$ & $3.02 E+04$ & $5.49 E+03$ & $7.61 E+03$ & 0.951 & $-1.54 E+04$ & $2.64 E+04$ \\
\hline & Sandwich & $-2.76 E+04$ & $9.53 \mathrm{E}+03$ & $0.033^{*}$ & $-5.37 E+04$ & $-1.43 E+03$ & $-2.04 E+04$ & $7.46 E+03$ & 0.051 & $-4.09 E+04$ & $4.81 E+01$ \\
\hline & Under & $-6.43 E+04$ & $9.67 E+03$ & $1.16 \mathrm{E}-09^{*}$ & $-9.09 E+04$ & $-3.78 E+04$ & $-4.74 E+04$ & $7.59 \mathrm{E}+03$ & $1.28 \mathrm{E}-08^{*}$ & $-6.82 E+04$ & $-2.66 \mathrm{E}+04$ \\
\hline
\end{tabular}

Figure 3.

(A) Single trial's calibration curves generated using each of the four methods of application with the error bars representing the standard deviation of eight microspots for each calibration solution. (B) Graph displaying the results from the tissues dosed in vitro with the error bars representing the standard deviation of at least three trials for MALDI MS/MS and at least five trials for HPLC-MS/MS. (C) Following an ANOVA, a posthoc Tukey test for differences was performed for each method on both tissues, yielding statistically significant differences from HPLC-MS/MS for MALDI premixed (tissue 2), MALDI sandwich (tissue 1), and MALDI under (tissues 1 and 2) standard application methods at the 0.05 level. No statistically significant differences from HPLC-MS/MS were detected for the MALDI analysis of either tissue when depositing the standards on the tissues followed by matrix application. 

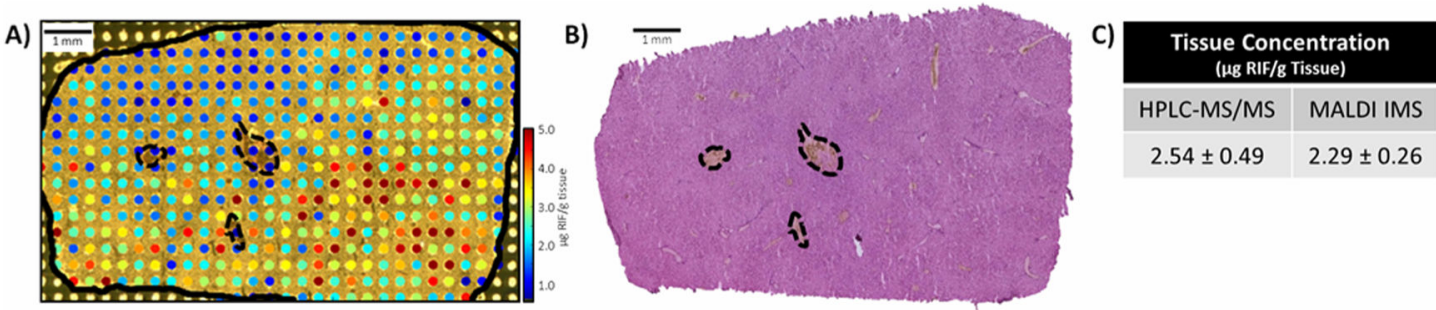

Figure 4.

Tissue sections (12 $\mu \mathrm{m}$ thick) from a liver dosed in vivo. (A) One section was quantitatively imaged at a spatial resolution of $350 \mu \mathrm{m}$ and shows little to no RIF detected in the blood vessels outlined with a black dotted line. A concentration gradient of RIF was also detected around the portal tracts (low to high), revealing the microphysiology of the drug within the liver. (B) A serial section was stained with hematoxylin and eosin for visualization of the blood vessels. (C) The MALDI IMS data and HPLC-MS/MS data are in agreement with $90.4 \%$ similarity. 